\title{
Influence of calcination temperature on iron titanate catalyst for the selective catalytic reduction of $\mathrm{NO}_{x}$ with $\mathrm{NH}_{3}$
}

\author{
Fudong Liu ${ }^{a}$, Kiyotaka Asakura ${ }^{b}$, Hong He ${ }^{a}, *$, Yongchun Liu ${ }^{a}$, Wenpo Shan ${ }^{a}$, \\ Xiaoyan Shi ${ }^{\mathrm{a}}$, Changbin Zhang ${ }^{\mathrm{a}}$ \\ a State Key Laboratory of Environmental Chemistry and Ecotoxicology, Research Center for Eco-Environmental Sciences, Chinese Academy of Sciences, Beijing 100085, PR China \\ b Catalysis Research Center, Hokkaido University, Sapporo 001-0021, Japan
}

\section{A R T I C L E I N F O}

\section{Article history:}

Available online 18 November 2010

\section{Keywords:}

Selective catalytic reduction

Iron titanate catalyst

Calcination temperature

Intrinsic SCR activity

Thermal stability

\begin{abstract}
A B S T R A C T
The influence of calcination temperature on the microstructure, redox behavior, reactant adsorption capability and catalytic activity of iron titanate catalyst $\left(\mathrm{FeTiO}_{x}\right)$ for the selective catalytic reduction (SCR) of $\mathrm{NO}_{x}$ with $\mathrm{NH}_{3}$ was investigated in detail using various characterization methods. After high temperature calcination (above $600^{\circ} \mathrm{C}$ ), the apparent SCR activity of $\mathrm{FeTiO}_{x}$ catalyst obviously decreased, which was mainly due to decrease of surface area, pore volume, mobility of lattice oxygen and reactant adsorption capability. However, well crystallized pseudobrookite $\mathrm{Fe}_{2} \mathrm{TiO}_{5}$ showed much higher intrinsic SCR activity after normalization by surface area. This is mainly owing to the formation of larger proportion of monodentate nitrate, which is the real reactive nitrate species in the $\mathrm{NO}_{x}$ reduction process, among total nitrate species on the surface of $\mathrm{FeTiO}_{x}$ catalysts with higher crystallization degree. This implies a possibility that the $\mathrm{FeTiO}_{x}$ catalyst after high temperature calcination $\left(600\right.$ or $\left.700^{\circ} \mathrm{C}\right)$ with higher thermal stability could be loaded onto porous support with large surface area to further improve its dispersion and thus the apparent SCR activity for practical use, such as the $\mathrm{DeNO}_{x}$ process for diesel engines.
\end{abstract}

(C) 2010 Elsevier B.V. All rights reserved.

\section{Introduction}

Selective catalytic reduction (SCR) of $\mathrm{NO}_{x}$ with $\mathrm{NH}_{3}$ is widely applied to the catalytic $\mathrm{DeNO}_{x}$ process for stationary and mobile sources [1]. Nowadays, many researchers are interested in the development of new $\mathrm{NH}_{3}$-SCR catalysts because of some inevitable disadvantages of the existing $\mathrm{V}_{2} \mathrm{O}_{5}-\mathrm{WO}_{3}\left(\mathrm{MoO}_{3}\right) / \mathrm{TiO}_{2}$ system in practical utilization, such as the narrow operation temperature window [2], the low $\mathrm{N}_{2}$ selectivity at high temperatures, the high conversion of $\mathrm{SO}_{2}$ to $\mathrm{SO}_{3}[3]$ and the toxicity of vanadium pentoxide [4]. US has already preferred not to use vanadium-based SCR catalysts in the $\mathrm{DeNO}_{x}$ process for mobile diesel engines [5,6].

Fe-based catalysts such as Fe/ZSM-5 [7-12], Fe/HBEA [13-16], $\mathrm{Fe}-\mathrm{TiO}_{2}-\mathrm{PILC}$ [17], $\mathrm{Fe}_{2} \mathrm{O}_{3} / \mathrm{WO}_{3} / \mathrm{ZrO}_{2}$ [18] and $\mathrm{Fe}-\mathrm{Mn} / \mathrm{USY}$ [19] usually show good SCR activity and $\mathrm{N}_{2}$ selectivity, and $\mathrm{TiO}_{2}$ is usually used as support for SCR catalysts because of its high resistance to $\mathrm{SO}_{2}$ poisoning [20]. Under the consideration to combine the merits of $\mathrm{Fe}$ active component and $\mathrm{TiO}_{2}$ support, in our previous study [21-23] we reported a novel and environmental-friendly iron titanate catalyst $\mathrm{FeTiO}_{x}$ prepared by co-precipitation method, showing high $\mathrm{NH}_{3}-\mathrm{SCR}$ activity, $\mathrm{N}_{2}$ selectivity and $\mathrm{H}_{2} \mathrm{O} / \mathrm{SO}_{2}$ dura-

\footnotetext{
* Corresponding author at: P.O. Box 2871, 18 Shuangqing Road, Haidian District Beijing 100085, PR China. Tel.: +86 1062849123 ; fax: +86 1062849123.

E-mail address: honghe@rcees.ac.cn (H. He).
}

bility in the medium temperature range $\left(250-400^{\circ} \mathrm{C}\right)$. However, the $\mathrm{FeTiO}_{x}$ catalyst was mainly prepared at low calcination temperature, such as $400^{\circ} \mathrm{C}$, to obtain large surface area and pore volume, supplying more active sites for the SCR reaction and thus increasing the apparent SCR activity. In the practical utilization, such as the $\mathrm{DeNO}_{x}$ process for diesel engines, the SCR reaction temperature may have sudden increase in some working conditions, resulting in the structural change and activity variation of $\mathrm{FeTiO}_{x}$ catalyst. Therefore, it is very necessary to investigate the influence of calcination temperature on $\mathrm{FeTiO}_{x}$ catalyst, which is also important for the further catalyst molding in practical use.

In this study, the microstructure of $\mathrm{FeTiO}_{x}$ catalysts with different calcination temperatures was characterized by thermal gravity and differential thermal analysis (TG-DTA), $\mathrm{N}_{2}$ physisorption, Fourier transform infrared absorption spectroscopy (FTIR absorption spectroscopy) and X-ray absorption fine structure spectroscopy (XAFS). The redox behavior of $\mathrm{FeTiO}_{x}$ serial catalysts was investigated by X-ray photoelectron spectroscopy (XPS) plus $\mathrm{H}_{2}$ temperature programmed reduction $\left(\mathrm{H}_{2}-\mathrm{TPR}\right)$, and the reactant adsorption capability was evaluated using $\mathrm{NH}_{3} / \mathrm{NO}_{x}$-temperature programmed desorption $\left(\mathrm{NH}_{3} / \mathrm{NO}_{x}-\mathrm{TPD}\right)$ together with in situ diffuse reflectance infrared Fourier transform spectroscopy (in situ DRIFTS) of $\mathrm{NH}_{3} / \mathrm{NO}_{x}$ adsorption. The experimental results in this study can supply some theoretical guidance for the optimization of preparation conditions and further industrial use of $\mathrm{FeTiO}_{x}$ catalyst. 


\section{Experimental}

\subsection{Catalyst synthesis and activity test}

$\mathrm{FeTiO}_{x}$ serial catalysts with different calcination temperatures $\left(400,500,600\right.$ and $\left.700^{\circ} \mathrm{C}\right)$ were prepared by conventional co-precipitation method using $\mathrm{Fe}\left(\mathrm{NO}_{3}\right)_{3} \cdot 9 \mathrm{H}_{2} \mathrm{O}$ and $\mathrm{Ti}\left(\mathrm{SO}_{4}\right)_{2}$ as precursors with Fe-Ti molar ratio of $1: 1$ and $\mathrm{NH}_{3} \cdot \mathrm{H}_{2} \mathrm{O}$ as precipitator, which are signed as $\mathrm{FeTiO}_{x}-400,500,600,700{ }^{\circ} \mathrm{C}$, respectively. The synthesis process has been described in detail in our previous study $[21,22]$.

The steady state $\mathrm{NH}_{3}$-SCR activity over $\mathrm{FeTiO}_{x}$ serial catalysts was tested in a fixed-bed quartz tube reactor at atmospheric pressure, and the reaction conditions were controlled as follows: 500 ppm NO, 500 ppm $\mathrm{NH}_{3}, 5$ vol.\% $\mathrm{O}_{2}, \mathrm{~N}_{2}$ balance; $0.6 \mathrm{ml}$ catalyst, 20-40 mesh; total flow rate of $500 \mathrm{ml} / \mathrm{min}$ and gas hourly space velocity $(\mathrm{GHSV})=50000 \mathrm{~h}^{-1}$. The effluent gas was continuously analyzed using an FTIR spectrometer (Nicolet Nexus 670) equipped with a heated, low volume multiple-path gas cell $(2 \mathrm{~m})$.

The transient state $\mathrm{NH}_{3}$-SCR activity over $\mathrm{FeTiO}_{x}$ serial catalysts was investigated using temperature programmed surface reaction (TPSR) in SCR condition. A quadrupole mass spectrometer (HPR20, Hiden Analytical Ltd.) was used to record the signal of $\mathrm{NO}(m / z=30)$. Prior to TPSR procedure, the catalysts ( $c a .100 \mathrm{mg}$ ) were firstly pretreated at $300^{\circ} \mathrm{C}$ for $0.5 \mathrm{~h}$ in a flow of $20 \mathrm{vol} . \% \mathrm{O}_{2} / \mathrm{He}(30 \mathrm{ml} / \mathrm{min})$ and cooled down to the room temperature. Then the catalysts were exposed to a flow of $500 \mathrm{ppm} \mathrm{NH}_{3}+500 \mathrm{ppm} \mathrm{NO}+5 \mathrm{vol} . \% \mathrm{O}_{2}$ $(30 \mathrm{ml} / \mathrm{min})$ for $1 \mathrm{~h}$ until the mass spectrometer signals were stabilized. Finally, the temperature was raised linearly to $500{ }^{\circ} \mathrm{C}$ at the rate of $10^{\circ} \mathrm{C} / \mathrm{min}$ in the same gas flow.

\subsection{Characterizations}

TG-DTA was conducted on a Shimadzu, DTG-60H apparatus to characterize the weight change and endothermal-exothermal status of $\mathrm{FeTiO}_{x}$ catalyst precursor (precipitate after drying in air at $100{ }^{\circ} \mathrm{C}$ for $12 \mathrm{~h}$ ) during the calcination procedure, then to infer the possible structural change and confirm the optimal catalyst calcination temperature. Before the measurement of TG-DTA curve, the $\mathrm{FeTiO}_{x}$ catalyst precursor ( $\mathrm{ca} .10 \mathrm{mg}$ ) was pretreated in air condition at $120^{\circ} \mathrm{C}$ for $1 \mathrm{~h}$, and then cooled down to $30^{\circ} \mathrm{C}$ holding for another $1 \mathrm{~h}$. Finally, the temperature was raised linearly to $950^{\circ} \mathrm{C}$ in air condition at the rate of $10^{\circ} \mathrm{C} / \mathrm{min}$. During this process, the desorption of $\mathrm{H}_{2} \mathrm{O}$ from $\mathrm{FeTiO}_{x}$ catalyst precursor might occur, therefore we also conducted another $\mathrm{H}_{2} \mathrm{O}$-temperature programmed desorption $\left(\mathrm{H}_{2} \mathrm{O}\right.$-TPD) experiment. Prior to the TPD procedure, the $\mathrm{FeTiO}_{x}$ catalyst precursor ( $c a .200 \mathrm{mg}$ ) was pretreated in a flow of $20 \mathrm{vol} . \%$ $\mathrm{O}_{2} / \mathrm{Ar}(30 \mathrm{ml} / \mathrm{min})$ at $120^{\circ} \mathrm{C}$ for $1 \mathrm{~h}$ and then cooled down to the room temperature holding for another $1 \mathrm{~h}$. In the same gas flow, the temperature was raised linearly to $950^{\circ} \mathrm{C}$ at the rate of $10^{\circ} \mathrm{C} / \mathrm{min}$. The $\mathrm{H}_{2} \mathrm{O}$ signal $(m / z=18)$ was monitored on-line using the abovementioned quadrupole mass spectrometer.

$\mathrm{N}_{2}$ adsorption-desorption isotherms over $\mathrm{FeTiO}_{x}$ serial catalysts were obtained at $-196^{\circ} \mathrm{C}$ using a Quantachrome Autosorb-1C instrument. Prior to $\mathrm{N}_{2}$ physisorption, the catalysts were degassed at $300^{\circ} \mathrm{C}$ for $4 \mathrm{~h}$. Surface areas were determined by BET equation in $0.05-0.35$ partial pressure range. Pore volumes, average pore diameters and pore size distributions were determined by Barrett-Joyner-Halenda $(\mathrm{BJH})$ method from the desorption branches of the isotherms.

FTIR absorption spectroscopy was measured in a transmission mode with an FTIR spectrometer (Nicolet Nexus 670) equipped with a DTGS detector. The catalysts were diluted by $\mathrm{KBr}$ with the weight ratio of 1:8000 and then pressed into wafers. Using the $\mathrm{KBr}$ wafer as background, the spectra were collected in the range of $4000-400 \mathrm{~cm}^{-1}$ with a resolution of $4 \mathrm{~cm}^{-1}$.
The XAFS including X-ray absorption near-edge spectroscopy (XANES) and extended X-ray absorption fine-structure spectroscopy (EXAFS) of $\mathrm{Fe}-\mathrm{K}$ and $\mathrm{Ti}-\mathrm{K}$ edges in $\mathrm{FeTiO}_{x}$ serial catalysts were measured in a transmission mode at room temperature on BL-7C beam line, Photon Factory, Institute of Materials Structure Science (IMSS-KEK), Japan. The storage ring was operated at $2.5 \mathrm{GeV}$ with $300 \mathrm{~mA}$ as an average storage current. The synchrotron radiation was monochromatized with a $\mathrm{Si}(111)$ double crystal monochromator, and mirrors were used to eliminate higher harmonics. The incident and transmitted beam intensities were monitored using ionization chambers filled with pure $\mathrm{N}_{2}$. Data were analyzed using REX2000 program (Rigaku Co.). XANES were normalized with edge height. EXAFS oscillation $\chi(k)$ was extracted using spline smoothing with a Cook-Sayers criterion [24], and the filtered $k^{3}$-weighted $\chi(k)$ was Fourier transformed into $R$ space $(k$ range: $2.5-15 \AA^{-1}$ for Fe-K EXAFS and $2.5-13 \AA^{-1}$ for Ti-K EXAFS).

XPS was recorded on a Scanning X-ray Microprobe (PHI Quantera, ULVAC-PHI, Inc.) using $\mathrm{Al} K_{\alpha}$ radiation. Binding energies of Fe 2 p and Ti 2 p were calibrated using $C 1$ s peak $(B E=284.8 \mathrm{eV})$ as standard.

$\mathrm{H}_{2}$-TPR experiments were carried out to investigate the influence of calcination temperature on the reducibility of $\mathrm{FeTiO}_{x}$ serial catalysts. Prior to the TPR procedure, the catalysts $(200 \mathrm{mg}$ ) were firstly pretreated in a flow of $20 \mathrm{vol} . \% \mathrm{O}_{2} / \mathrm{Ar}(30 \mathrm{ml} / \mathrm{min})$ at $300{ }^{\circ} \mathrm{C}$ for $30 \mathrm{~min}$ and then cooled down to the room temperature. In a flow of $5 \mathrm{vol} . \% \mathrm{H}_{2} / \mathrm{Ar}(30 \mathrm{ml} / \mathrm{min})$, the temperature was raised linearly to $900^{\circ} \mathrm{C}$ at the rate of $10^{\circ} \mathrm{C} / \mathrm{min}$. The $\mathrm{H}_{2}$ signal $(\mathrm{m} / \mathrm{z}=2)$ was monitored on-line using the above-mentioned quadrupole mass spectrometer.

$\mathrm{NH}_{3} / \mathrm{NO}_{x}$-TPD experiments were performed on $200 \mathrm{mg}$ catalysts using the above-mentioned quadrupole mass spectrometer to record the signals of $\mathrm{NH}_{3}(m / z=16)$ and $\mathrm{NO}_{x}(m / z=30)$. Prior to the TPD procedure, the catalysts were pretreated at $300^{\circ} \mathrm{C}$ for $0.5 \mathrm{~h}$ in a flow of $20 \mathrm{vol} . \% \mathrm{O}_{2} / \mathrm{He}(30 \mathrm{ml} / \mathrm{min})$ and cooled down to the room temperature. Then the catalysts were exposed to a flow of $2500 \mathrm{ppm} \mathrm{NH} /$ Ar or $2500 \mathrm{ppm} \mathrm{NO}+10$ vol.\% $\mathrm{O}_{2} / \mathrm{Ar}(30 \mathrm{ml} / \mathrm{min}$ ) for $1 \mathrm{~h}$, following by Ar purge for another $1 \mathrm{~h}$. Finally, the temperature was raised linearly to $500^{\circ} \mathrm{C}$ in Ar flow at the rate of $10^{\circ} \mathrm{C} / \mathrm{min}$.

The in situ DRIFTS experiments of $\mathrm{NH}_{3} / \mathrm{NO}_{x}$ adsorption over $\mathrm{FeTiO}_{x}$ catalysts were performed on an FTIR spectrometer (Nicolet Nexus 670) equipped with an MCT/A detector cooled by liquid nitrogen. An in situ DRIFTS reactor cell with ZnSe window (Nexus Smart Collector) connected to an adsorption/purging gas control system was used for $\mathrm{NH}_{3} / \mathrm{NO}_{x}$ in situ adsorption experiments. The temperature of the reactor cell was controlled precisely by an Omega programmable temperature controller. Prior to $\mathrm{NH}_{3} / \mathrm{NO}_{x}$ adsorption, the catalysts were pretreated at $400^{\circ} \mathrm{C}$ in a flow of $20 \mathrm{vol} . \% \mathrm{O}_{2} / \mathrm{N}_{2}$ for $0.5 \mathrm{~h}$ and cooled down to $30^{\circ} \mathrm{C}$. The spectra of different catalysts at $30^{\circ} \mathrm{C}$ were collected in flowing $\mathrm{N}_{2}$ and set as backgrounds, which were automatically subtracted from the final spectra after $\mathrm{NH}_{3} / \mathrm{NO}_{x}$ adsorption. Then the catalysts were exposed to a flow of $500 \mathrm{ppm} \mathrm{NH}_{3} / \mathrm{N}_{2}$ or $500 \mathrm{ppm} \mathrm{NO}+5 \mathrm{vol} . \%$ $\mathrm{O}_{2} / \mathrm{N}_{2}(300 \mathrm{ml} / \mathrm{min})$ at $30^{\circ} \mathrm{C}$ for $1 \mathrm{~h}$, following by $\mathrm{N}_{2}$ purge for another $0.5 \mathrm{~h}$. All spectra were recorded by accumulating 100 scans with a resolution of $4 \mathrm{~cm}^{-1}$.

\section{Results and discussion}

\section{1. $\mathrm{NH}_{3}-\mathrm{SCR}$ activity}

Fig. 1 shows the steady state $\mathrm{NH}_{3}$-SCR activity and TPSR results in SCR condition over $\mathrm{FeTiO}_{x}$ catalysts with different calcination temperatures, based on which the influence of calcination temperature on the catalytic performance of $\mathrm{FeTiO}_{x}$ catalysts can be fully investigated. From the results we can see that, with the 


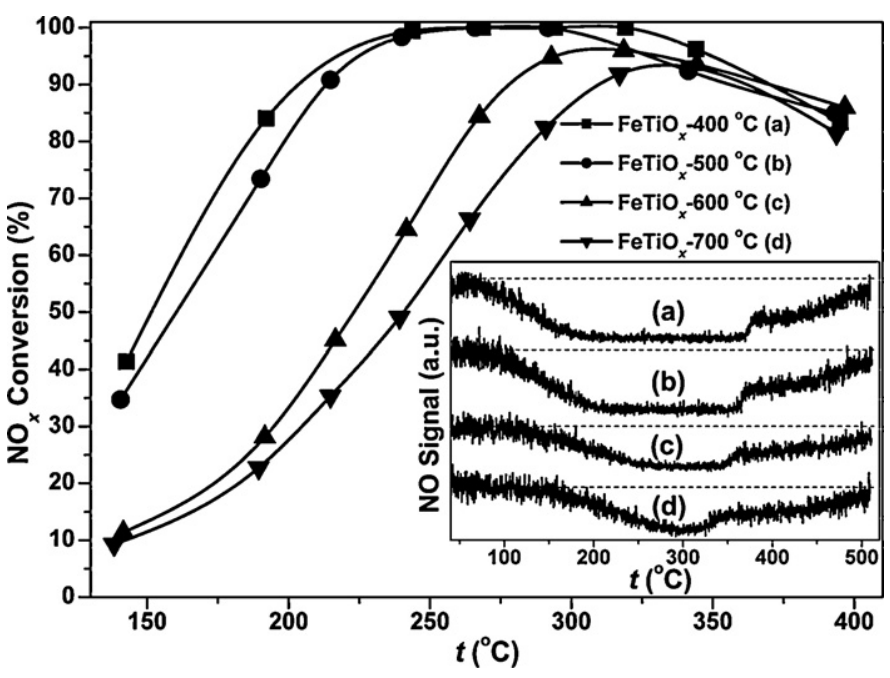

Fig. 1. Steady state $\mathrm{NH}_{3}-\mathrm{SCR}$ activity and TPSR results over $\mathrm{FeTiO}_{x}$ catalysts with different calcination temperatures.

increasing of calcination temperature, the steady state $\mathrm{NO}_{x}$ conversion showed an obvious decrease below $300^{\circ} \mathrm{C}$, and retained nearly the same above $300^{\circ} \mathrm{C}$. Comparing with $\mathrm{FeTiO}_{x}-400^{\circ} \mathrm{C}$ catalyst, $\mathrm{FeTiO}_{x}-500^{\circ} \mathrm{C}$ catalyst showed similar catalytic activity in the whole temperature range with $\mathrm{NO}_{x}$ conversion above $90 \%$ from 225 to $375^{\circ} \mathrm{C}$, while $\mathrm{FeTiO}_{x}-600^{\circ} \mathrm{C}$ and $\mathrm{FeTiO}_{x}-700^{\circ} \mathrm{C}$ catalysts showed much lower SCR activity in the low temperature range, indicating the possible severe structural change of $\mathrm{FeTiO}_{x}$ catalysts after calcination at high temperatures $\left(600\right.$ or $\left.700^{\circ} \mathrm{C}\right)$. As shown in Fig. S1, the $\mathrm{NH}_{3}$ conversion in the SCR reaction over $\mathrm{FeTiO}_{x}$ catalysts with different calcination temperatures followed nearly the same trend as that of $\mathrm{NO}_{x}$ conversion, while the $\mathrm{N}_{2}$ selectivity showed some slight decrease with the increasing of catalyst calcination temperature. The TPSR results in the inset figure also shows that the temperature point to achieve the minimum NO concentration over $\mathrm{FeTiO}_{x}$ catalysts after high temperature calcination was greatly delayed, and the catalyst operation temperature window was also narrowed, which is in well accordance with the steady state SCR activity test. In the following sections, we will fully investigate the influence of calcination temperature on the microstructure, redox behavior and reactant adsorption capability of $\mathrm{FeTiO}_{x}$ catalyst using various characterization methods.

\subsection{Structural property}

\subsubsection{TG-DTA and $\mathrm{H}_{2} \mathrm{O}-\mathrm{TPD}$}

Fig. 2 shows the TG-DTA curve and $\mathrm{H}_{2} \mathrm{O}$-TPD results of $\mathrm{FeTiO}_{x}$ catalyst precursor. With the linear increasing of calcination temperature, the TG curve presented that the $\mathrm{FeTiO}_{x}$ catalyst precursor showed an obvious weight loss due to the occurrence of dehydration effect. After calcination at 400 or $500^{\circ} \mathrm{C}$, the weight loss achieved $7.75 \%$. Combining the DTA and $\mathrm{H}_{2} \mathrm{O}$-TPD results we can see that, the endothermal peak and $\mathrm{H}_{2} \mathrm{O}$ desorption peak below $150{ }^{\circ} \mathrm{C}$ corresponded to the desorption of physisorbed $\mathrm{H}_{2} \mathrm{O}$. The three exothermal peaks and $\mathrm{H}_{2} \mathrm{O}$ desorption peaks in the range of $200-360^{\circ} \mathrm{C}$ corresponded to the desorption of $\mathrm{H}_{2} \mathrm{O}$ produced by the acid-base neutralization reaction between basic hydroxyls in $\mathrm{Fe}(\mathrm{OH})_{x}$ [25] and acidic hydroxyls in $\mathrm{Ti}(\mathrm{OH})_{x}$ (orthotitanic acid or metatitanic acid) [26], in which process the iron titanate crystallite with specific Fe-O-Ti structure was formed. The endothermal peak and $\mathrm{H}_{2} \mathrm{O}$ desorption peak in the range of $400-450{ }^{\circ} \mathrm{C}$ was due to the desorption of surface hydroxyls from iron titanate crystallite, which means that further increasing the calcination temperature could result in the decrease of surface Brønsted acid sites and thus the decrease of $\mathrm{NH}_{3}$ adsorption amount in the SCR reaction condition. Above $600^{\circ} \mathrm{C}$, there was no $\mathrm{H}_{2} \mathrm{O}$ desorption peak detected, and only an obvious endothermal peak was observed possibly due to the catalyst crystallization or phase transformation/separation. From 500 to $800^{\circ} \mathrm{C}$, the weight loss of $\mathrm{FeTiO}_{x}$ catalyst precursor was only $0.60 \%$, which might be caused by the decomposition of residual sulfate species from $\mathrm{Ti}\left(\mathrm{SO}_{4}\right)_{2}$ precursor.

\subsection{2. $N_{2}$ physisorption}

Fig. S2 shows the $\mathrm{N}_{2}$ adsorption-desorption isotherms and pore size distributions of $\mathrm{FeTiO}_{x}$ serial catalysts. For $\mathrm{FeTiO}_{x}-400^{\circ} \mathrm{C}$ catalyst, the isotherm at low $P / P_{0}$ resembled closely with type IV isotherm according to the IUPAC classification [27], which is typical for mesoporous materials. However, at high $P / P_{0}$ the isotherm shifted from type IV to type II pattern, indicating the presence of some macropores in this sample. In addition, the hysteresis loop exhibited typical H3 type, revealing the slit-shaped pore structure in this catalyst [27]. With the increasing of calcination temperature, the $\mathrm{N}_{2}$ adsorbed volume per weight showed an obvious decrease, and the closure point of hysteresis loop also moved to the higher $P / P_{0}$, indicating that much more macropores were formed after high temperature calcination. The pore size distributions also show that with the increasing of calcination temperature, the ratios of micropores and mesopores in $\mathrm{FeTiO}_{x}$ catalysts were continuously decreased, and eventually mainly mesopores and macropores existed after 600 or $700^{\circ} \mathrm{C}$ calcination.

Table 1 shows the structural parameters of $\mathrm{FeTiO}_{x}$ catalysts with different calcination temperatures derived from $\mathrm{N}_{2}$ physisorption results and the SCR reaction rates normalized by surface areas. After high temperature calcination, both surface area and pore volume showed an obvious decrease and the average pore diameter showed an evident increase, which is an important reason for the decline of apparent SCR activity. However, after normalization by surface areas, the $\mathrm{SCR}$ reaction rates over $\mathrm{FeTiO}_{x}$ catalysts with high temperature calcination $\left(600\right.$ or $\left.700^{\circ} \mathrm{C}\right)$ were much higher than those over $\mathrm{FeTiO}_{x}$ catalysts with low temperature calcination (400 or $500^{\circ} \mathrm{C}$ ), which shows that well crystallized iron titanate catalyst also showed outstanding SCR activity due to the possession of Fe-O-Ti structure, although the amount of Fe-O-Ti structure exposed on the catalyst surface was greatly lowered due to the occurrence of crystallization or phase transformation. In practical use, such as the $\mathrm{DeNO}_{x}$ process for diesel engine exhaust, the operation temperature of SCR catalyst might have some sudden increase in some working conditions, and $\mathrm{FeTiO}_{x}$ catalysts with high calcination temperatures will be more appropriate to be utilized for this

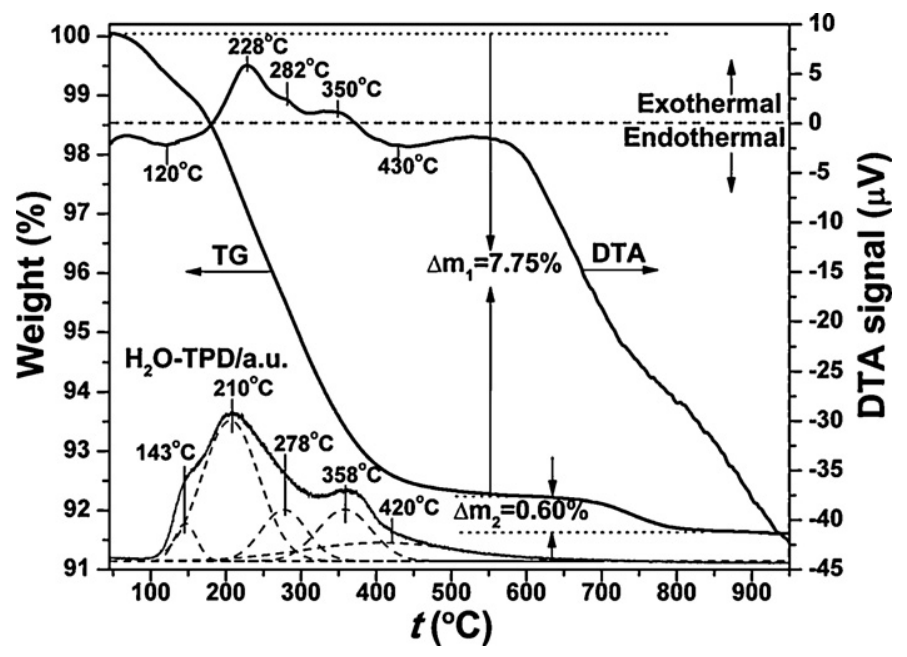

Fig. 2. TG-DTA curve and $\mathrm{H}_{2} \mathrm{O}-\mathrm{TPD}$ results of $\mathrm{FeTiO}_{x}$ catalyst precursor. 
Table 1

Structural parameters of $\mathrm{FeTiO}_{x}$ catalysts with different calcination temperatures and SCR reaction rates normalized by surface areas.

\begin{tabular}{|c|c|c|c|c|}
\hline Catalysts & $S_{\mathrm{BET}}{ }^{\mathrm{a}}\left(\mathrm{m}^{2} \mathrm{~g}^{-1}\right)$ & Pore volume ${ }^{\mathrm{b}}\left(\mathrm{cm}^{3} \mathrm{~g}^{-1}\right)$ & Pore diameter ${ }^{c}(\mathrm{~nm})$ & $\begin{array}{l}\text { Reaction rates at } 1500^{\circ} \\
\left(10^{-10} \mathrm{~mol} \mathrm{~s}^{-1} \mathrm{~m}^{-2}\right)\end{array}$ \\
\hline $\mathrm{FeTiO}_{x}-400^{\circ} \mathrm{C}$ & 245.3 & 0.52 & 8.3 & $8.83\left(48 \% \mathrm{DeNO}_{x}\right)$ \\
\hline $\mathrm{FeTiO}_{x}-500^{\circ} \mathrm{C}$ & 150.6 & 0.47 & 12.2 & $11.82\left(42 \% \mathrm{DeNO}_{x}\right)$ \\
\hline $\mathrm{FeTiO}_{x}-600^{\circ} \mathrm{C}$ & 48.3 & 0.37 & 30.7 & $12.06\left(14 \% \mathrm{DeNO}_{x}\right)$ \\
\hline $\mathrm{FeTiO}_{x}-700^{\circ} \mathrm{C}$ & 28.1 & 0.30 & 43.2 & $15.83\left(12 \% \mathrm{DeNO}_{x}\right)$ \\
\hline
\end{tabular}

a BET surface area.

b BJH desorption pore volume.

c Average pore diameter.

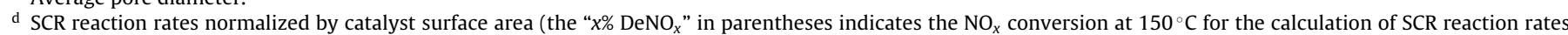
over different $\mathrm{FeTiO}_{x}$ catalysts).

process due to their higher thermal stability. To further increase the apparent SCR activity, it is possible to load $\mathrm{FeTiO}_{x}$ catalysts after high temperature calcination $\left(600\right.$ or $\left.700^{\circ} \mathrm{C}\right)$ onto porous support with large surface area to improve their dispersion and thus increase the number of active sites for the SCR reaction.

\subsubsection{FTIR absorption spectroscopy}

The XRD results in our previous study showed that the $\mathrm{FeTiO}_{x^{-}}$ $400^{\circ} \mathrm{C}$ catalyst was mainly in the form of iron titanate crystallite with no obvious diffraction peaks, and with the increasing of calcination temperature from 500 to $700{ }^{\circ} \mathrm{C}$, well crystallized pseudobrookite $\mathrm{Fe}_{2} \mathrm{TiO}_{5}$ and rutile $\mathrm{TiO}_{2}$ were formed [21]. Fig. 3 shows the FTIR absorption spectroscopy of $\mathrm{FeTiO}_{x}$ catalysts with different calcination temperatures measured in a transmission mode, which can supply more information about the microstructure of $\mathrm{FeTiO}_{x}$ serial catalysts. As we can see, all samples showed the FTIR absorption bands at 3421 and $1635 \mathrm{~cm}^{-1}$, which are attributed to surface hydroxyls and adsorbed $\mathrm{H}_{2} \mathrm{O}$, respectively. With the increasing of calcination temperature, especially to 600 or $700{ }^{\circ} \mathrm{C}$, the band intensity of $\mathrm{O}-\mathrm{H}$ stretching vibration mode at $3421 \mathrm{~cm}^{-1}$ showed some decrease, implying the occurrence of dehydroxylation effect and thus the decrease of surface Brønsted acid sites, which is in well accordance with the TG-DTA results. In the fundamental vibration region, only a broad band centered at $561 \mathrm{~cm}^{-1}$ was observed for $\mathrm{FeTiO}_{x}-400^{\circ} \mathrm{C}$ catalyst, which probably can be ascribed to the multiple absorptions of $\mathrm{Fe}-\mathrm{O}, \mathrm{Ti}-\mathrm{O}$ and $\mathrm{Fe}-\mathrm{O}-\mathrm{Ti}$ groups. Increasing the calcination temperature to $600{ }^{\circ} \mathrm{C}$ resulted in the splitting of this broad band into two sub-bands at 615 and $492 \mathrm{~cm}^{-1}$, and further increasing to 700 and $800{ }^{\circ} \mathrm{C}$ resulted in the formation of three distinct sub-bands, which implies that the microstructure of $\mathrm{FeTiO}_{x}$

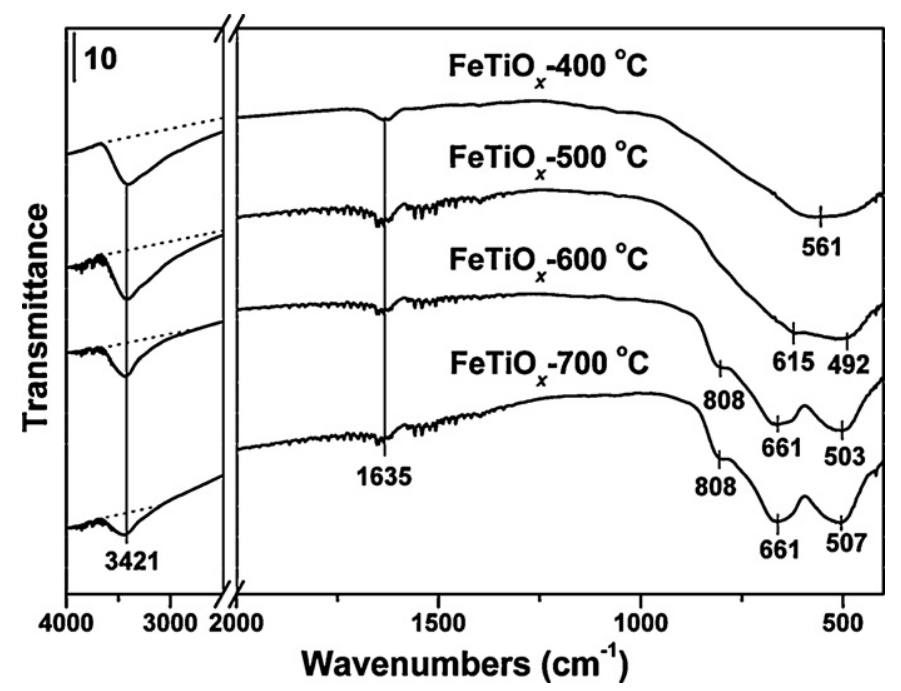

Fig. 3. FTIR absorption spectroscopy of $\mathrm{FeTiO}_{x}$ catalysts with different calcination temperatures. catalysts showed obvious change during the calcination process. Among the three sub-bands, the bands at 808 and $661 \mathrm{~cm}^{-1}$ were attributed to the fundamental vibrations of $\mathrm{Fe}_{2} \mathrm{TiO}_{5}$ [28], and the band at 503 or $507 \mathrm{~cm}^{-1}$ was attributed to the fundamental vibration of Ti-O group in rutile $\mathrm{TiO}_{2}$ [29]. No fundamental vibration of $\mathrm{Fe}-\mathrm{O}$ group in $\mathrm{Fe}_{2} \mathrm{O}_{3}$ was observed [30], which is in well accordance with our previous XRD results [21].

\subsubsection{XAFS}

Fig. 4 shows the XAFS results of $\mathrm{FeTiO}_{x}$ catalysts with different calcination temperatures. As the XANES results in Fig. $4 \mathrm{~A}$ and $\mathrm{C}$ shown, both of the pre-edge peaks of $\mathrm{Fe}-\mathrm{K}$ and $\mathrm{Ti}-\mathrm{K}$ edges in $\mathrm{FeTiO}_{x}$ serial catalysts showed an obvious decrease in intensity with the increasing of calcination temperature. Our previous study already showed that the pre-edge peak intensity in XANES spectra was positively correlated with the structural distortion of specific element [22,31]. For example, smaller pre-edge peak intensity implied that well crystallized coordination shell existed around the target element. Therefore, the XANES results in this study indicate that the coordination structures of both Fe species and Ti species were transformed from severely distorted octahedron to more symmetrical octahedron, which is closely associated with the increasing of crystallization degree after high temperature calcination.

Fig. $4 \mathrm{~B}$ and $\mathrm{D}$ shows the Fourier transforms of filtered EXAFS oscillations $k^{3} \cdot \chi(k)$ of $\mathrm{Fe}-\mathrm{K}$ and $\mathrm{Ti}-\mathrm{K}$ edges in $\mathrm{FeTiO}_{x}$ serial catalysts into $R$ space. As we concluded in our previous study [22], the first coordination peaks of $\mathrm{Fe}-\mathrm{K}$ and $\mathrm{Ti}-\mathrm{K}$ edges in $\mathrm{FeTiO}_{x}-400^{\circ} \mathrm{C}$ catalyst were ascribed to $\mathrm{Fe}-\mathrm{O}$ and $\mathrm{Ti}-\mathrm{O}$ coordination shells, and the second single coordination peaks were ascribed to $\mathrm{Fe}-\mathrm{O}-\mathrm{Ti}$ and $\mathrm{Ti}-\mathrm{O}-\mathrm{Fe}$ coordination shells. The weak intensity of the second coordination peaks implies that the $\mathrm{FeTiO}_{x}-400^{\circ} \mathrm{C}$ catalyst was mainly in the form of iron titanate crystallite with specific Fe-O-Ti structure containing abundant structural defects, which is beneficial to the adsorption and activation of reactants in the SCR reaction. With the increasing of calcination temperature, the first coordination peaks of $\mathrm{Fe}-\mathrm{K}$ and $\mathrm{Ti}-\mathrm{K}$ edges showed no obvious change, however, the second single coordination peaks gradually split into two groups of sub-bands, with higher peak intensity and larger bond distance. According to the previous XRD results [21] and above-mentioned FTIR absorption spectroscopy, the sub-bands of Fe-K edge mainly consisted of $\mathrm{Fe}-\mathrm{O}-\mathrm{Ti}$ and $\mathrm{Fe}-\mathrm{O}-\mathrm{Fe}$ bonds from $\mathrm{Fe}_{2} \mathrm{TiO}_{5}$, and the sub-bands of Ti-K edge mainly consisted of Ti-O-Fe, Ti-O-Ti bonds from $\mathrm{Fe}_{2} \mathrm{TiO}_{5}$ and $\mathrm{Ti}-\mathrm{O}-\mathrm{Ti}$ bond from rutile $\mathrm{TiO}_{2}$. The larger bond distance of $\mathrm{Fe}-\mathrm{O}-\mathrm{Ti}$ or $\mathrm{Ti}-\mathrm{O}-\mathrm{Fe}$ structure arose by high temperature calcination might result in the weakening of the interaction between $\mathrm{Fe}$ and $\mathrm{Ti}$ species to a certain extent. Although the high temperature calcination resulted in the severe change of the second coordination shells, the $\mathrm{Fe}-\mathrm{O}-\mathrm{Ti}$ or $\mathrm{Ti}-\mathrm{O}-\mathrm{Fe}$ structure (i.e. the first sub-band with higher intensity) was still present in well crystallized $\mathrm{Fe}_{2} \mathrm{TiO}_{5}$, continuing to perform high specific catalytic activity in the SCR reaction. Summarizing the TG-DTA, $\mathrm{N}_{2}$ physisorption, FTIR absorption spectroscopy and XAFS results, it is concluded that 

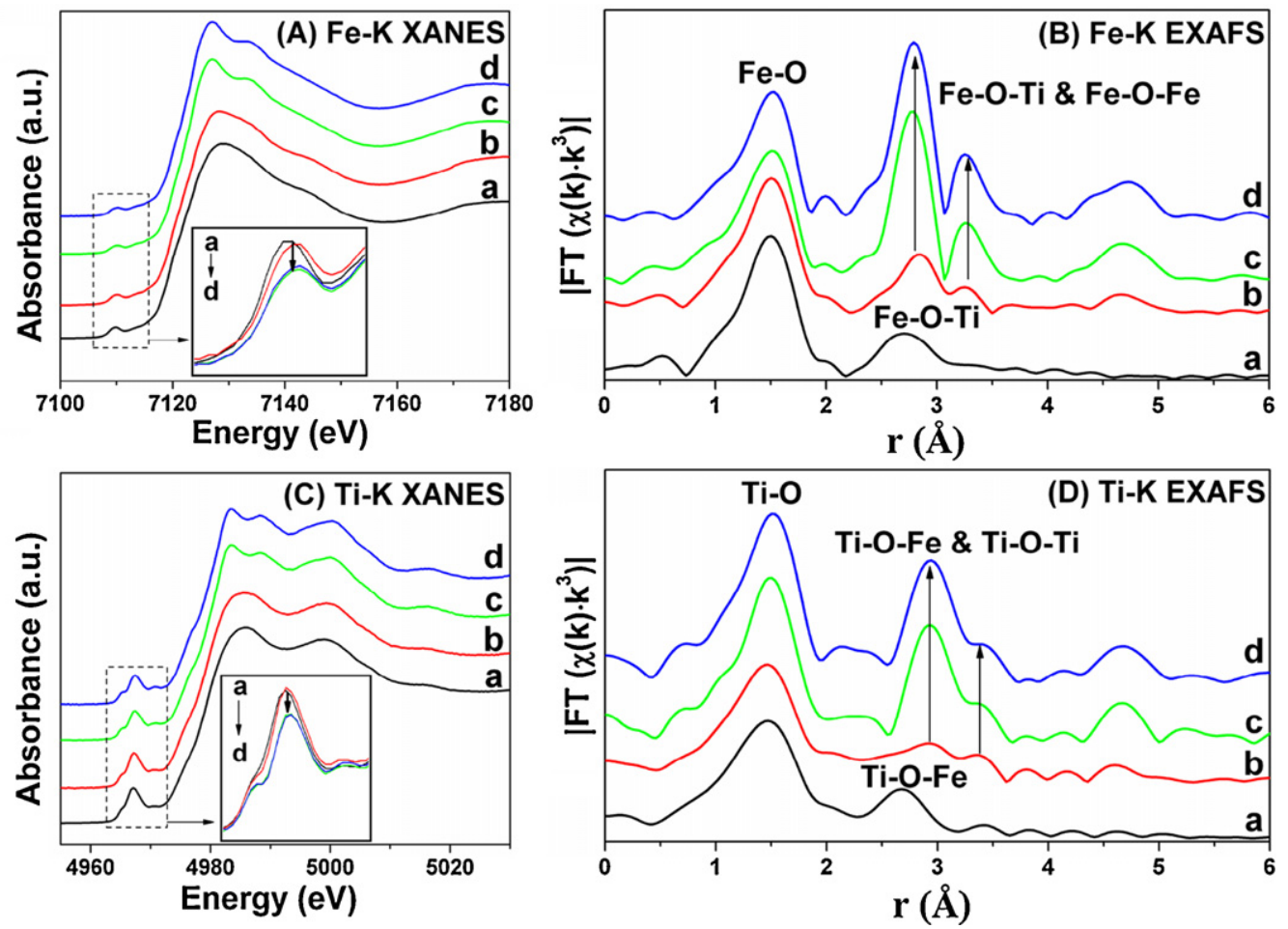

Fig. 4. XAFS results of $\mathrm{FeTiO}_{x}$ catalysts with different calcination temperatures: (a) $\mathrm{FeTiO}_{x}-400{ }^{\circ} \mathrm{C}$; $(\mathrm{b}) \mathrm{FeTiO}_{x}-500{ }^{\circ} \mathrm{C}$; $(\mathrm{c}) \mathrm{FeTiO}_{x}-600{ }^{\circ} \mathrm{C}$; $(\mathrm{d}) \mathrm{FeTiO}_{x}-700^{\circ} \mathrm{C}$.

the high temperature calcination led to the enhancement of crystallization degree of $\mathrm{FeTiO}_{x}$ catalyst, together with the decrease of surface area, pore volume, surface Brønsted acid sites, the number of structural defects and thus the apparent SCR activity.

\subsection{Redox behavior}

\subsubsection{XPS}

Fig. S3 shows the XPS results of $\mathrm{FeTiO}_{x}$ catalysts with different calcination temperatures. As shown in Fig. S3A, the binding energies of Fe $2 \mathrm{p}_{3 / 2}(711.2 \mathrm{eV})$ and $\mathrm{Fe} 2 \mathrm{p}_{1 / 2}(724.9 \mathrm{eV})$ in $\mathrm{FeTiO}_{x}$ serial catalysts corresponded well with those of $\mathrm{Fe}^{3+}[32,33]$, and no obvious change of Fe $2 \mathrm{p}$ binding energies was observed after high temperature calcination. In our previous study [22,23], we concluded that there was an electronic inductive effect between $\mathrm{Fe}^{3+}$ and $\mathrm{Ti}^{4+}$ species resulting in the enhancement of oxidative ability of $\mathrm{Fe}^{3+}$ species, and in this study the high temperature calcination did not change this situation. This result means that the surface $\mathrm{Fe}^{3+}$ species still showed high oxidative ability after high temperature calcination owing to the preservation of $\mathrm{Fe}-\mathrm{O}-\mathrm{Ti}$ structure in well crystallized $\mathrm{Fe}_{2} \mathrm{TiO}_{5}$. As shown in Fig. S3B, the binding energies of Ti $2 \mathrm{p}_{3 / 2}(458.6 \mathrm{eV})$ and Ti $2 \mathrm{p}_{1 / 2}(464.2 \mathrm{eV})$ in $\mathrm{FeTiO}_{x}-400^{\circ} \mathrm{C}$ and $\mathrm{FeTiO}_{x}-500^{\circ} \mathrm{C}$ catalysts were typical characteristics of $\mathrm{Ti}^{4+}[32,33]$, and after 600 or $700^{\circ} \mathrm{C}$ calcination the binding energies of these two peaks shifted to 458.8 and $464.4 \mathrm{eV}$ mainly due to the separation of partial rutile $\mathrm{TiO}_{2}$ without strong electronic interaction with $\mathrm{Fe}^{3+}$ species. Summarizing the Fe 2p and Ti 2p XPS results we can see that, the apparent SCR activity decline of $\mathrm{FeTiO}_{x}$ catalysts after high temperature calcination was not caused by the binding energy change of active $\mathrm{Fe}^{3+}$ species, but due to the high crystallization degree of pseudobrookite $\mathrm{Fe}_{2} \mathrm{TiO}_{5}$ accompanied by the separation of partial rutile $\mathrm{TiO}_{2}$ and thus the decrease of catalytic active sites.

\subsection{2. $\mathrm{H}_{2}-\mathrm{TPR}$}

To further elucidate the influence of calcination temperature on the reducibility of $\mathrm{FeTiO}_{x}$ serial catalysts, we also conducted
$\mathrm{H}_{2}$-TPR experiments and the results are shown in Fig. 5 . To better understand the reduction process of $\mathrm{Fe}^{3+}$ species, the overlapped $\mathrm{H}_{2}$ reduction peaks were deconvoluted into several sub-bands by searching for the optimal combination of Gaussian bands with the correlation coefficients $\left(r^{2}\right)$ above 0.99 without fixing the sub-band positions (PeakFit software package, Version 4.12, SeaSolve Software Inc.). The sub-bands are signed as $a, b, c$ from low to high temperatures, in which $a$ donates the reduction of surface oxygen, $b$ donates the reduction of $\mathrm{Fe}^{3+}$ to $\mathrm{Fe}^{(3-\delta)+}(\delta=1 / 3)$ and $c$ donates the further reduction of $\mathrm{Fe}^{(3-\delta)+}$ to $\mathrm{Fe}^{2+}$ plus partial $\mathrm{Fe}^{0} . b_{1}, b_{2}$, $c_{1}$, and $c_{2}$ sub-bands refer to the reduction of iron species in different oxide layers of $\mathrm{FeTiO}_{x}$ serial catalysts, such as the surface layer $\left(b_{1}, c_{1}\right)$ and the bulk layer $\left(b_{2}, c_{2}\right)$. According to our previous study $[22,23]$, all $\mathrm{Fe}^{3+}$ species in $\mathrm{FeTiO}_{x}-400^{\circ} \mathrm{C}$ catalyst can be reduced to $\mathrm{Fe}^{2+}$ by $\mathrm{H}_{2}$ below $500^{\circ} \mathrm{C}$, and partial $\mathrm{Fe}^{2+}$ species can be further reduced to metallic $\mathrm{Fe}^{0}$ above $500^{\circ} \mathrm{C}$. The area ratio of sub-

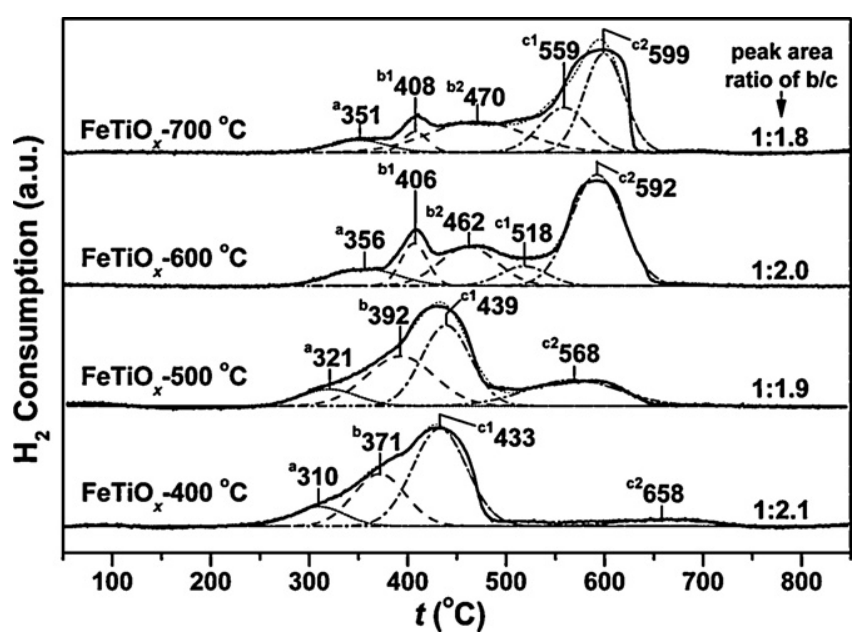

Fig. 5. $\mathrm{H}_{2}$-TPR results of $\mathrm{FeTiO}_{x}$ catalysts with different calcination temperatures. 

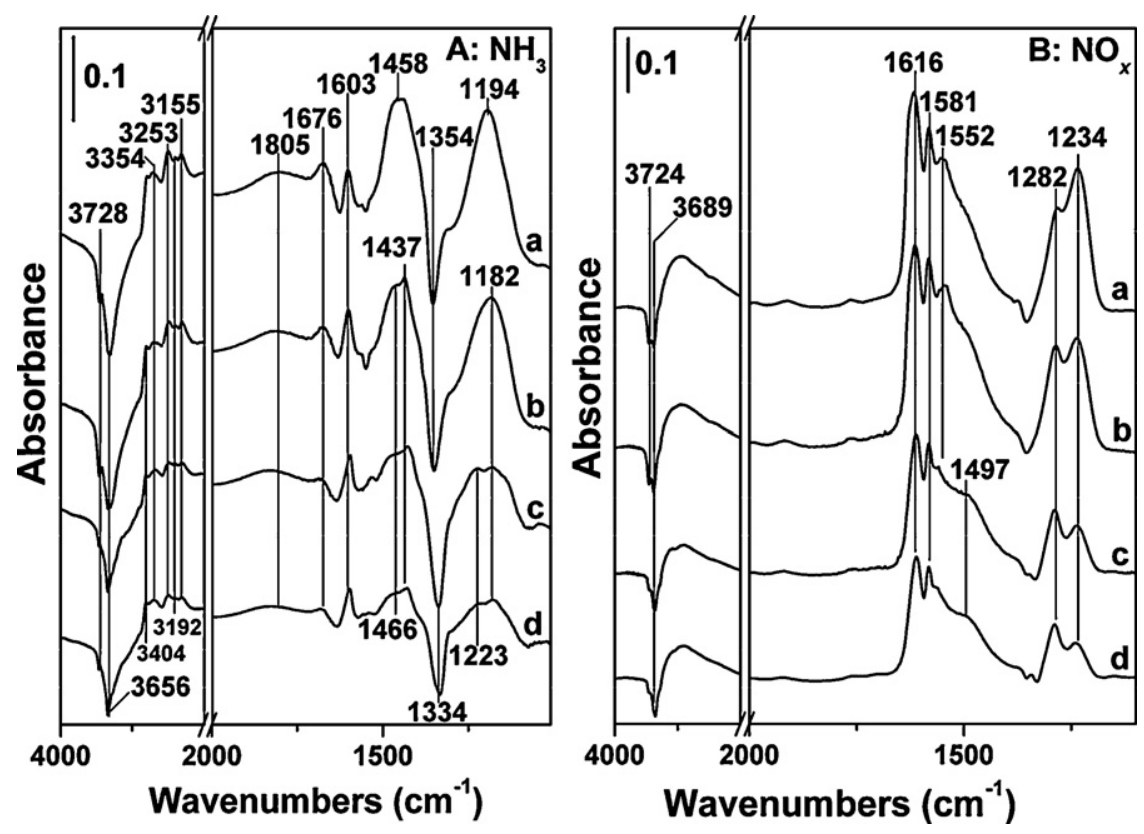

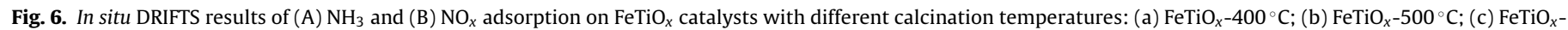
$600{ }^{\circ} \mathrm{C}$; (d) $\mathrm{FeTiO}_{x}-700^{\circ} \mathrm{C}$.

bands $b / c(1: 2.1)$ on $\mathrm{FeTiO}_{x}-400{ }^{\circ} \mathrm{C}$ catalyst in the present study is in well accordance with our previous conclusion. With the increasing of calcination temperature, the reduction temperature of surface oxygen (sub-bands $a$ ) was increased to a certain extent, and the reduction process of $\mathrm{Fe}^{3+}$ species also showed obvious variation. Remarkably, the sub-bands $b$ and $c$ shifted to the high temperature region, and more iron species was reduced in the bulk layer when the $\mathrm{FeTiO}_{x}$ catalysts were calcined at high temperatures. For example, a majority of iron species in $\mathrm{FeTiO}_{x}-600^{\circ} \mathrm{C}$ and $\mathrm{FeTiO}_{x^{-}}$ $700^{\circ} \mathrm{C}$ catalysts was largely reduced around $600^{\circ} \mathrm{C}$. Although the $\mathrm{Fe}^{3+}$ species in all $\mathrm{FeTiO}_{x}$ catalysts can be reduced to $\mathrm{Fe}^{2+}$ below $800{ }^{\circ} \mathrm{C}$ based on the area ratio of sub-bands $b / c(1: 1.8 \sim 1: 2.1)$, the reducibility of the catalysts after high temperature calcination was actually lowered. This means that the mobility of lattice oxygen was greatly weakened in this process, which is possibly associated with the inhibition of $\mathrm{H}_{2}$ diffusion into the bulk phase of $\mathrm{FeTiO}_{x}$ catalysts with high crystallization degree after high temperature calcination. The weakening of the mobility of lattice oxygen made a majority of $\mathrm{Fe}^{3+}$ species firmly confined in the crystal structure of $\mathrm{FeTiO}_{x}$ catalysts, which was not beneficial to the accomplishment of redox cycle between $\mathrm{Fe}^{3+}$ and $\mathrm{Fe}^{2+}$, thus leading to the decrease of low temperature apparent SCR activity.

\subsection{Reactants adsorption capability}

\subsection{1. $\mathrm{NH}_{3} / \mathrm{NO}_{x}-\mathrm{TPD}$}

In $\mathrm{NH}_{3}-\mathrm{SCR}$ reaction, especially in the low temperature range, both of $\mathrm{NH}_{3}$ and $\mathrm{NO}_{x}$ can adsorb onto the catalyst surface and participate into the $\mathrm{NO}_{x}$ reduction process, therefore, we conducted $\mathrm{NH}_{3} / \mathrm{NO}_{x}$-TPD experiments over $\mathrm{FeTiO}_{x}$ serial catalysts and the results are shown in Fig. S4. As the $\mathrm{NH}_{3}$-TPD results shown in Fig. S4A, there were three groups of $\mathrm{NH}_{3}$ desorption peaks detected over all samples, among which the peaks between 50 and $80^{\circ} \mathrm{C}$ were attributed to the desorption of physisorbed $\mathrm{NH}_{3}$, the peaks between 100 and $130^{\circ} \mathrm{C}$ to the desorption of $\mathrm{NH}_{4}{ }^{+}$bound to weak Brønsted acid sites [34,35], and the peaks above $200^{\circ} \mathrm{C}$ to the multiple desorption of $\mathrm{NH}_{4}{ }^{+}$bound to strong Brønsted acid sites plus coordinated $\mathrm{NH}_{3}$ bound to Lewis acid sites [36]. With the increasing of calcination temperature, the total desorption amount of $\mathrm{NH}_{3}$ over $\mathrm{FeTiO}_{x}$ serial catalysts showed an obvious and monotonic decrease, and the desorption ratio of $\mathrm{NH}_{4}{ }^{+}$bound to Brønsted acid sites also showed some decrease to a certain extent. This result indicates that besides of the decline of $\mathrm{NH}_{3}$ adsorption amount caused by the decrease of surface area after high temperature calcination, the number of Brønsted acid sites was also decreased due to the dehydroxylation effect, which is in well accordance with the above-mentioned TG-DTA results and FTIR absorption spectroscopy. Our previous study showed that ionic $\mathrm{NH}_{4}{ }^{+}$was the main active adsorbed $\mathrm{NH}_{3}$ species in the SCR reaction at low temperatures [37], therefore, the SCR activity decline over $\mathrm{FeTiO}_{x}$ catalysts after high temperature calcination was closely associated with the decrease of surface Brønsted acid sites.

As the $\mathrm{NO}_{x}$-TPD results shown in Fig. $\mathrm{S} 4 \mathrm{~B}$, there were three groups of $\mathrm{NO}_{x}$ desorption peaks detected over all samples, among which the peaks below $160^{\circ} \mathrm{C}$ was ascribed to the decomposition of monodentate nitrate, the peaks between 200 and $270^{\circ} \mathrm{C}$ to the decomposition of bridging nitrate, and the peaks between 320 and $330^{\circ} \mathrm{C}$ to the decomposition of bidentate nitrate $[23,31,37]$. With the increasing of calcination temperature, the total desorption amount of $\mathrm{NO}_{x}$ over $\mathrm{FeTiO}_{x}$ serial catalysts also showed an obvious and monotonic decrease, which was caused by the decrease of surface areas. Except the increasing of the decomposing temperature of bridging nitrate species over $\mathrm{FeTiO}_{x}$ catalysts after high temperature calcination (from 203 to $261{ }^{\circ} \mathrm{C}$ ), no obvious variation of thermal stability was observed for other nitrate species. It is noticeable that with the increasing of calcination temperature, only the band intensity of bridging nitrate and bidentate nitrate showed obvious decrease, yet the band intensity of monodentate nitrate kept constant. Therefore, the adsorption ratio of $\mathrm{NO}_{x}$ as monodentate nitrate was actually enhanced in this process, which might be relevant with the increasing of intrinsic SCR activity over $\mathrm{FeTiO}_{x}-600^{\circ} \mathrm{C}$ and $\mathrm{FeTiO}_{x}-700^{\circ} \mathrm{C}$ catalysts.

\subsubsection{In situ DRIFTS of $\mathrm{NH}_{3} / \mathrm{NO}_{x}$ adsorption}

To investigate the surface adsorbed species after $\mathrm{NH}_{3}$ or $\mathrm{NO}_{x}$ adsorption, we carried out the in situ DRIFTS experiments of $\mathrm{NH}_{3} / \mathrm{NO}_{x}$ adsorption on $\mathrm{FeTiO}_{x}$ serial catalysts with different calcination temperatures, and the results are presented in Fig. 6. After 
$\mathrm{NH}_{3}$ adsorption and $\mathrm{N}_{2}$ purge, as shown in Fig. $6 \mathrm{~A}$, the catalyst surface was mainly covered by ionic $\mathrm{NH}_{4}{ }^{+}$bound to Brønsted acid sites $\left(1676 \mathrm{~cm}^{-1}\right.$ and $\left.1437-1466 \mathrm{~cm}^{-1}\right)[38,39]$ and coordinated $\mathrm{NH}_{3}$ bound to Lewis acid sites $\left(1603 \mathrm{~cm}^{-1}\right.$ and $1182-1223 \mathrm{~cm}^{-1}$ ) $[39,40]$. At the same time, the bands attributed to $\mathrm{N}-\mathrm{H}$ stretching vibration modes at $3100-3400 \mathrm{~cm}^{-1}$, the hydroxyl consumption bands at 3728 and $3656 \mathrm{~cm}^{-1}$ due to the interaction between $\mathrm{NH}_{3}$ and surface acidic hydroxyls, and the negative bands at $1334-1354 \mathrm{~cm}^{-1}$ caused by the coverage of residual sulfate species from $\mathrm{Ti}\left(\mathrm{SO}_{4}\right)_{2}$ precursor by $\mathrm{NH}_{3}$ also showed up. With the increasing of calcination temperature, both of the bands attributed to ionic $\mathrm{NH}_{4}{ }^{+}$and coordinated $\mathrm{NH}_{3}$ showed an obvious decrease in intensity, which is directly correlated with the decrease of surface acidic hydroxyls (i.e. Brønsted acid sites) and surface oxygen defects (i.e. Lewis acid sites) during the crystallization process.

As shown in Fig. 6B, after $\mathrm{NO}_{x}$ adsorption and $\mathrm{N}_{2}$ purge, the catalyst surface was mainly covered by monodentate nitrate $\left(1497-1552 \mathrm{~cm}^{-1}\right.$ and $\left.1282 \mathrm{~cm}^{-1}\right)$, bridging nitrate (1616 and $\left.1234 \mathrm{~cm}^{-1}\right)$ and bidentate nitrate $\left(1581 \mathrm{~cm}^{-1}\right)$, and the hydroxyl consumption bands at 3724 and $3689 \mathrm{~cm}^{-1}$ due to the interaction between surface basic hydroxyls and $\mathrm{NO}_{x}$ also showed up [41-45]. With the increasing of calcination temperature, the total adsorption amount of the three kinds of nitrate species showed obvious decrease, which is in well accordance with the $\mathrm{NO}_{x}$-TPD results. However, it is noticeable that, although the absolute adsorption amount of monodentate nitrate on $\mathrm{FeTiO}_{x}$ catalysts after high temperature calcination was decreased, the relative adsorption amount of monodentate nitrate among the three kinds of nitrate species was obviously increased. For instance, on $\mathrm{FeTiO}_{x}-600^{\circ} \mathrm{C}$ and $\mathrm{FeTiO}_{x^{-}}$ $700{ }^{\circ} \mathrm{C}$ catalysts, the band intensity of $v_{3}$ low vibration mode of monodentate nitrate at $1282 \mathrm{~cm}^{-1}$ was even higher than that of bridging nitrate at $1234 \mathrm{~cm}^{-1}$. In our previous study [23], we have already concluded that monodentate nitrate was the real active $\mathrm{NO}_{x}$ adsorbed species in $\mathrm{NH}_{3}$-SCR reaction at low temperatures. Due to the strong adsorption of $\mathrm{NH}_{3}$ onto $\mathrm{FeTiO}_{x}$ catalyst surface, the low temperature SCR activity was directly correlated to the adsorption amount of monodentate nitrate. Therefore, in this study, the increase of the SCR reaction rates normalized by surface areas over $\mathrm{FeTiO}_{x}$ catalysts after high temperature calcination was mainly due to the enhancement of the relative adsorption amount of monodentate nitrate among total nitrate species on catalyst surface.

In short summary, after high temperature calcination (600 or $700^{\circ} \mathrm{C}$ ), the well crystallized $\mathrm{FeTiO}_{x}$ catalysts with low surface area and pore volume would have smaller amount of surface acid sites and lower mobility of lattice oxygen (i.e. redox ability between $\mathrm{Fe}^{3+}$ and $\mathrm{Fe}^{2+}$ ), which was not beneficial to the adsorption and activation of $\mathrm{NH}_{3}$ or $\mathrm{NO}_{x}$, thus leading to the decrease of apparent SCR activity. However, the adsorption of $\mathrm{NO}_{x}$ as highly reactive monodentate nitrate was actually enhanced to a certain extent after high temperature calcination, thus resulting in the increase of intrinsic SCR activity. In future preparation process of $\mathrm{FeTiO}_{x}$ catalyst for practical use, the three factors for controlling the SCR activity including redox ability of Fe species, surface acidity and adsorption capability of monodentate nitrate can be adjusted and balanced by tuning the calcination temperatures.

\section{Conclusions}

The calcination temperature in the preparation process showed obvious influence on the microstructure, redox behavior, reactant adsorption capability of the $\mathrm{FeTiO}_{x}$ serial catalysts and thus the relevant $\mathrm{NH}_{3}$-SCR activity. After high temperature calcination (600 or $700^{\circ} \mathrm{C}$ ), well crystallized pseudobrookite $\mathrm{Fe}_{2} \mathrm{TiO}_{5}$ appeared in $\mathrm{FeTiO}_{x}$ catalyst, leading to the decrease of surface area, pore volume, the mobility of lattice oxygen, the reactant adsorption capabil- ity and thus the apparent SCR activity. However, $\mathrm{FeTiO}_{x}-600^{\circ} \mathrm{C}$ or $\mathrm{FeTiO}_{x}-700^{\circ} \mathrm{C}$ catalyst showed higher thermal stability and intrinsic SCR activity after normalization by surface area, which is closely associated with the formation of larger proportion of monodentate nitrate among total nitrate species on catalyst surface. In the future study, $\mathrm{FeTiO}_{x}$ catalysts after high temperature calcination can be loaded onto porous support with large surface area to further improve their dispersion and thus the apparent SCR activity in practical use.

\section{Acknowledgements}

This work was partially supported by the National High Technology Research and Development Program of China (2009AA064802 and 2009AA06Z301), the National Natural Science Foundation of China (50921064), the Photon Factory, KEK, Japan (Project No. 2009G177) and JSPS, Japan (Frontier Human Resources Development Project: Creation of Sustainable Catalysts for the New 21st Society).

\section{Appendix A. Supplementary data}

Supplementary data associated with this article can be found, in the online version, at doi:10.1016/j.cattod.2010.10.008.

\section{References}

[1] H. Bosch, F. Janssen, Catal. Today 2 (1988) 369

[2] G. Busca, L. Lietti, G. Ramis, F. Berti, Appl. Catal. B: Environ. 18 (1998) 1.

[3] J.P. Dunn, P.R. Koppula, H.G. Stenger, I.E. Wachs, Appl. Catal. B: Environ. 19 (1998) 103.

[4] Vanadium Pentoxide, MSDS No. V2220, Mallinckrodt Baker, Phillipsburg, NJ, July 1, 2009. http://www.jtbaker.com/msds/englishhtml/v2220.htm (accessed 20.01.10).

[5] R. Baker, M. Block, Diesel Construction Equipment Database and $\mathrm{NO}_{x}$ Control Technology Evaluation for Houston, Final Report for Texas Environmenta Research Consortium-New Technology Research and Development Program, 2007.

[6] S.-S. Adolf, P. Marcus, S. Paul, D. Yvonne, K. Thomas, L. Egbert, US Patents US2005/0196333A0196331 (2005).

[7] M. Schwidder, M.S. Kumar, A. Brückner, W. Grünert, Chem. Commun. (2005) 805

[8] M. Devadas, O. Kröcher, M. Elsener, A. Wokaun, G. Mitrikas, N. Söger, M. Pfeifer, Y. Demel, L. Mussmann, Catal. Today 119 (2007) 137.

[9] M. Iwasaki, K. Yamazaki, K. Banno, H. Shinjoh, J. Catal. 260 (2008) 205

[10] A.Z. Ma, W. Grünert, Chem. Commun. (1999) 71.

[11] R.Q. Long, R.T. Yang, J. Am. Chem. Soc. 121 (1999) 5595.

[12] J. Li, R. Zhu, Y. Cheng, C.K. Lambert, R.T. Yang, Environ. Sci. Technol. 44 (2010) 1799 .

[13] A. Frey, S. Mert, J. Due-Hansen, R. Fehrmann, C. Christensen, Catal. Lett. 130 (2009) 1.

[14] M. Høj, M.J. Beier, J.-D. Grunwaldt, S. Dahl, Appl. Catal. B: Environ. 93 (2009) 166.

[15] P. Balle, B. Geiger, S. Kureti, Appl. Catal. B: Environ. 85 (2009) 109.

[16] P. Balle, B. Geiger, D. Klukowski, M. Pignatelli, S. Wohnrau, M. Menzel, I. Zirkwa, G. Brunklaus, S. Kureti, Appl. Catal. B: Environ. 91 (2009) 587.

[17] R.Q. Long, R.T. Yang, J. Catal. 186 (1999) 254.

[18] N. Apostolescu, B. Geiger, K. Hizbullah, M.T. Jan, S. Kureti, D. Reichert, F. Schott W. Weisweiler, Appl. Catal. B: Environ. 62 (2006) 104.

[19] Q. Lin, J. Li, L. Ma, J. Hao, Catal. Today 151 (2010) 251

[20] F. Nakajima, I. Hamada, Catal. Today 29 (1996) 109.

[21] F. Liu, H. He, C. Zhang, Chem. Commun. (2008) 2043.

[22] F. Liu, H. He, C. Zhang, Z. Feng, L. Zheng, Y. Xie, T. Hu, Appl. Catal. B: Environ. 96 (2010) 408.

[23] F. Liu, H. He, J. Phys. Chem. C 114 (2010) 16929.

[24] J.W. Cook, D.E. Sayers, J. Appl. Phys. 52 (1981) 5024

[25] J. Baltrusaitis, J.H. Jensen, V.H. Grassian, J. Phys. Chem. B 110 (2006) 12005.

[26] S. Matsuda, A. Kato, Appl. Catal. 8 (1983) 149.

[27] K.S.W. Sing, D.H. Everett, R.A.W. Haul, L. Moscou, R.A. Pierotti, J. Rouquerol, T. Siemieniewska, Pure Appl. Chem. 57 (1985) 603.

[28] http://rruff.info/pseudobrookite/names/asc (accessed 20.06.10).

[29] S.K. Samantaray, T. Mishra, K.M. Parida, J. Mol. Catal. A: Chem. 156 (2000) 267.

[30] B. Pal, M. Sharon, G. Nogami, Mater. Chem. Phys. 59 (1999) 254.

[31] F. Liu, H. He, Y. Ding, C. Zhang, Appl. Catal. B: Environ. 93 (2009) 194.

[32] E.P. Reddy, L. Davydov, P.G. Smirniotis, J. Phys. Chem. B 106 (2002) 3394

[33] S. Roy, B. Viswanath, M.S. Hegde, G. Madras, J. Phys. Chem. C 112 (2008) 6002 .

[34] L.S. Cheng, R.T. Yang, N. Chen, J. Catal. 164 (1996) 70. 
[35] R.Q. Long, R.T. Yang, J. Catal. 207 (2002) 158.

[36] L. Chmielarz, R. Dziembaj, T. Grzybek, J. Klinik, T. Łojewski, D. Olszewska, A. Węrzynn, Catal. Lett. 70 (2000) 51.

[37] F. Liu, H. He, C. Zhang, W. Shan, X. Shi, Catal. Today, this issue.

[38] N.-Y. Topsøe, Science 265 (1994) 1217.

[39] F. Liu, H. He, Catal. Today 153 (2010) 70.

[40] G. Ramis, M.A. Larrubia, G. Busca, Top. Catal. 11-12 (2000) 161.
[41] Z. Liu, P.J. Millington, J.E. Bailie, R.R. Rajaram, J.A. Anderson, Micropor. Mesopor. Mater. 104 (2007) 159.

[42] G. Piazzesi, M. Elsener, O. Kröcher, A. Wokaun, Appl. Catal. B: Environ. 65 (2006) 169.

[43] W.S. Kijlstra, D.S. Brands, E.K. Poels, A. Bliek, J. Catal. 171 (1997) 208.

[44] W.S. Kijlstra, D.S. Brands, H.I. Smit, E.K. Poels, A. Bliek, J. Catal. 171 (1997) 219.

[45] G.M. Underwood, T.M. Miller, V.H. Grassian, J. Phys. Chem. A 103 (1999) 6184. 